\title{
Fahr's disease
}

\section{Anuradha Mookerjee, ${ }_{1}^{1}$ Anita Mehta, ${ }^{2}$ Udit Chaddha, ${ }^{3}$ Shivang Desai ${ }^{4}$}

1 Department of Medicine, Cooper University Hospital, Moorestown, New Jersey, USA ${ }^{2}$ Department of Medicine, GMC, Kolhapur, Maharashtra, India

${ }^{3}$ Department of Medicine, University of Louisville, Louisville, Kentucky, USA ${ }^{4}$ Department of Radiodiagnosis, Padmashree Dr D Y Patil Univeristy, Mumbai, Maharashtra, India

\section{Correspondence to} Dr Anuradha Mookerjee, mookerjee-anuradha@ cooperhealth.edu

\section{CrossMark}

To cite: Mookerjee $\mathrm{A}$, Mehta A, Chaddha U, et al. BMJ Case Rep Published online: [please include Day Month Year] doi:10.1136/ bcr-2013-201556

\section{DESCRIPTION}

An 18-year-old girl with a history of hypocalcaemic seizure disorder, diagnosed at 14 years, refractory to treatment with phenytoin, phenobarbital and valproate, presented with three new episodes of generalised tonic-clonic seizures. In addition to some cognitive impairment, on examination she had a positive Trousseau sign (flexion of the wrist and metacarpophalangeal joints when blood pressure cuff if inflated above the systolic blood pressure), and brisk reflexes with ankle clonus. Laboratory studies revealed calcium $6.5 \mathrm{mg} / \mathrm{dL}(8.5-10.5 \mathrm{mg} / \mathrm{dL})$, phosphorus $6.5 \mathrm{mg} / \mathrm{dL} \quad(3-4.5 \mathrm{mg} / \mathrm{dL})$, parathyroid hormone $134 \mathrm{pg} / \mathrm{dL}(17-70 \mathrm{pg} / \mathrm{dL})$ and 25-hydroxyl vitamin D $32 \mathrm{ng} / \mathrm{dL}(30-65 \mathrm{ng} / \mathrm{dL})$. CT of the brain revealed bilateral symmetrical calcification of the caudate nucleus, lenticular nucleus (putamen+globus pallidus), thalamus (figure 1) and the dentate nucleus of the cerebellum (figure 2). She was diagnosed with striatopallidodentate calcinosis (or Fahr's disease) secondary to hypocalcaemia due to pseudohypoparathyroidism type $\mathrm{Ib}$. Her calcium levels were corrected, and she followed up with $24 \mathrm{~h}$ urinary calcium levels for titration of therapy.

Fahr's disease is a neurodegenerative syndrome associated with symmetric intracerebral calcifications in the basal ganglia and adjacent parenchyma, and cognitive, neuropsychological and movement disorders. In 1850, Delacour first described vascular calcifications of the basal ganglia and Bamberger-described histopathological entity. ${ }^{1}$ While bilateral striatopallidodentate calcinosis is commonly referred to as 'Fahr's disease', there are

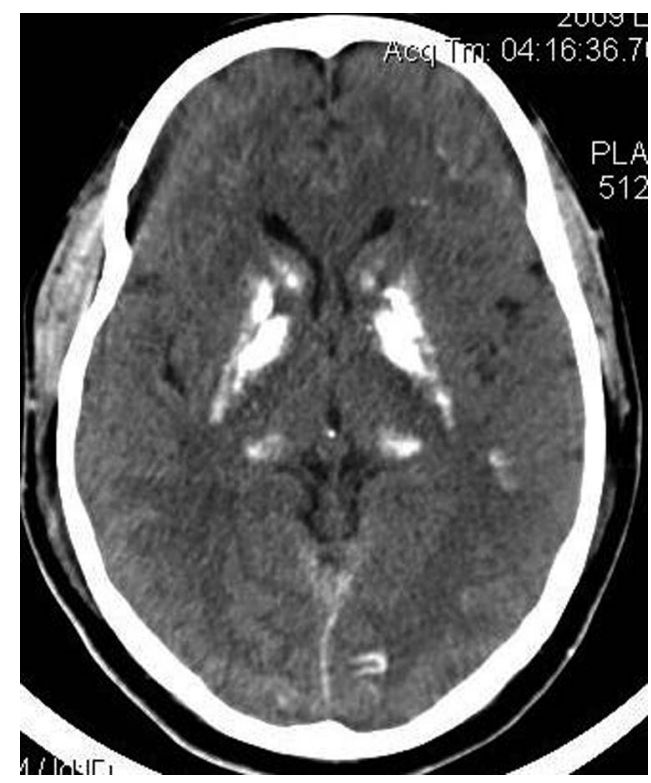

Figure 1 CT of the brain demonstrating bilateral symmetrical calcification of the caudate nucleus, lenticular nucleus (putamen+globus pallidus), thalamus.
35 additional names used in the literature for the same condition. Fahr's name became associated with all forms of bilateral calcifications in the basal ganglia and other parts of the brain, despite the fact that he was not the first to describe calcification in the brain. Secondary bilateral calcification is also reported in a variety of genetic, developmental, endocrine, metabolic and infectious conditions. ${ }^{2}$ This is an atypical presentation of striatopallidodentate calcinosis which is almost always a movement disorder with or without cognitive impairment.

Findings of low calcium and high phosphate levels are consistent with true hypoparathyroidism. However, elevated parathyroid hormone levels reflect hormone resistance, hence the name pseudohypoparathyroidism. There are four types of pseudohypoparathyroidism types $\mathrm{Ia}, \mathrm{Ib}, \quad \mathrm{II}$ and pseudopseudohypoparathyroidism. Our patient had type $\mathrm{Ib}$ pseudohypoparathyroidism as there was an absence of the Albright phenotype (short fourth and fifth metacarpals that is a classic symptom for type Ia). ${ }^{3}$

\section{Learning points}

- Know the presentation of Fahr's disease.

- Recognise secondary causes of bilateral striatopallidodentate calcinosis.

- Understand the biochemical abnormalities in psuedo-hypo-parathyrodism.

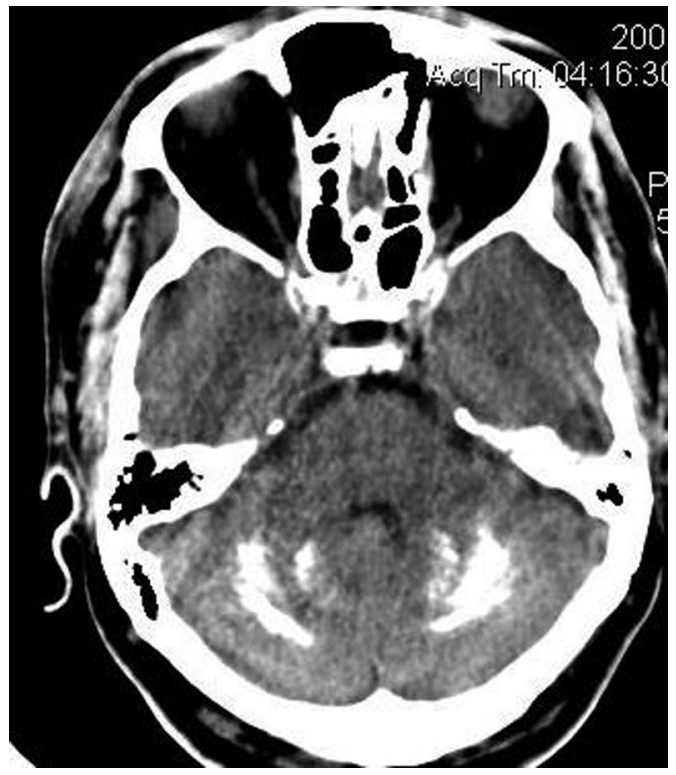

Figure 2 Dentate nucleus of the cerebellum on CT scan. 
Contributors AMo participated in structure, content and lead author, review of the final manuscript. UC participated in image acquisition and review of the final manuscript. AMe participated in content, reference, review the final manuscript and literature search. SD participated in review of the final version of the manuscript, detailed explanation about the images. All the authors were involved in the writing and approval of the submitted version.

Competing interests None.

Patient consent Obtained.
Provenance and peer review Not commissioned; externally peer reviewed.

\section{REFERENCES}

1 Morgante L, Trimarchi F, Benvenga S. Fahr's disease. Lancet 2002;359:759.

2 Manyam BV. What is and what is not 'Fahr's disease'. Parkinsonism Relat Disord 2005;11:73-80.

3 Desai N, Kalra A. Short fourth and fifth metacarpals. JAMA 2012;308:1034-5.

Copyright 2013 BMJ Publishing Group. All rights reserved. For permission to reuse any of this content visit http://group.bmj.com/group/rights-licensing/permissions.

BMJ Case Report Fellows may re-use this article for personal use and teaching without any further permission.

Become a Fellow of BMJ Case Reports today and you can:

- Submit as many cases as you like

- Enjoy fast sympathetic peer review and rapid publication of accepted articles

- Access all the published articles

- Re-use any of the published material for personal use and teaching without further permission

For information on Institutional Fellowships contact consortiasales@bmjgroup.com

Visit casereports.bmj.com for more articles like this and to become a Fellow 